\title{
Single-dose mRNA vaccine effectiveness against SARS-CoV-2 in healthcare workers extending 16 weeks post-vaccination: a test- negative design from Quebec, Canada
}

\author{
Sara Carazo ${ }^{1}$, Denis Talbot ${ }^{1,2}$, Nicole Boulianne ${ }^{3}$, Marc Brisson ${ }^{1,2,4}$, Rodica Gilca ${ }^{1,2,3}$, Geneviève \\ Deceuninck $^{1}$, Nicholas Brousseau ${ }^{1,2,3}$, Mélanie Drolet ${ }^{1}$, Manale Ouakki $^{3}$, Chantal Sauvageau $^{2,3}$, \\ Sapha Barkati ${ }^{5,6}$, Elise Fortin ${ }^{3}$, Alex Carignan7 ${ }^{7}$ Philippe De Wals ${ }^{2,3}$, Danuta M. Skowronski ${ }^{8}$,
} Gaston De Serres ${ }^{1,2,3}$

${ }^{1}$ Centre de Recherche du CHU de Quebec-Universite Laval, Quebec City, Quebec, Canada

${ }^{2}$ Social and preventive medicine department, Faculty of medicine, Laval University, Quebec city, Quebec, Canada

${ }^{3}$ Biological and occupational risks. Institut national de sante publique du Quebec, Quebec City, Quebec, Canada

${ }^{4}$ Department of Infectious Disease Epidemiology, Imperial College London, UK

5JD MacLean Centre for Tropical Diseases, McGill University Health Centre, McGill University, Montreal, Canada.

${ }^{6}$ Department of Medicine, Division of Infectious Diseases, McGill University Health Center, McGill University, Montreal, Quebec, Canada.

${ }^{7}$ Department of Microbiology and Infectious Diseases, Sherbrooke University, Sherbrooke, Quebec, Canada.

${ }^{8}$ Communicable Diseases and Immunization Services, BC Centre for Disease Control, Vancouver, British Columbia, Canada 
medRxiv preprint doi: https://doi.org/10.1101/2021.07.19.21260445; this version posted July 22, 2021. The copyright holder for this preprint (which was not certified by peer review) is the author/funder, who has granted medRxiv a license to display the preprint in perpetuity. It is made available under a CC-BY-NC-ND 4.0 International license .

Key words: SARS-CoV-2; COVID-19; vaccine effectiveness; healthcare workers; test-negative design

Short title: Single dose COVID-19 VE up to 16 weeks

\section{Corresponding author:}

Gaston De Serres MD, PhD

Biological and occupational risks

Institut national de santé publique du Québec

2400, Avenue d'Estimauville

Quebec, Quebec

G1E 7G9, Canada

Phone: +1 4185590780

E-mail: gaston.deserres@inspq.qc.ca 
medRxiv preprint doi: https://doi.org/10.1101/2021.07.19.21260445; this version posted July 22, 2021. The copyright holder for this preprint

(which was not certified by peer review) is the author/funder, who has granted medRxiv a license to display the preprint in perpetuity.

It is made available under a CC-BY-NC-ND 4.0 International license.

\section{ABSTRACT}

Introduction: In Canada, first and second doses of mRNA vaccines against SARS-CoV-2 were uniquely spaced 16 weeks apart, but the duration of single-dose protection remains uncertain. We estimated one- and two-dose mRNA vaccine effectiveness (VE) among healthcare workers (HCWs) in Quebec, Canada including protection against varying outcome severity, variants of concern (VOC), and the stability of single-dose protection out to 16 weeks post-vaccination. Methods: A test-negative design compared vaccination among SARS-CoV-2 test-positive and weekly-matched (10:1), randomly-sampled, test-negative HCWs using linked surveillance and immunization databases. Vaccine status was defined by one dose $\geq 14$ days or two doses $\geq 7$ days before illness onset or specimen collection. Adjusted VE was estimated by conditional logistic regression.

Results: Primary analysis included 5,316 cases and 53,160 controls. Single-dose VE was 70\% (95\%Cl: 68-73) against SARS-CoV-2 infection, 73\% (95\%Cl: 71-75) against COVID-19 illness and 97\% (95\%Cl: 92-99) against associated hospitalization. Two-dose VE was 86\% (95\%Cl: 81-90) and 93\% (95\%Cl: 89-95), respectively, with no associated hospitalizations. VE was higher for non-VOC than VOC (73\% Alpha) among single-dose (77\%, 95\%Cl: $73-81$ versus $63 \%$, 95\%Cl: $57-67)$ but not two-dose recipients (87\%, 95\%Cl: 57-96 versus 94\%, 95\%Cl: 89-96). Across 16 weeks, no decline in single-dose VE was observed with appropriate stratification based upon prioritized vaccination determined by higher versus lower likelihood of direct patient contact.

Conclusion: One mRNA vaccine dose provided substantial and sustained protection to HCWs extending at least four months post-vaccination. In circumstances of vaccine shortage, delaying the second dose may be a pertinent public health strategy to consider. 
medRxiv preprint doi: https://doi.org/10.1101/2021.07.19.21260445; this version posted July 22, 2021. The copyright holder for this preprint

(which was not certified by peer review) is the author/funder, who has granted medRxiv a license to display the preprint in perpetuity.

It is made available under a CC-BY-NC-ND 4.0 International license .

\section{INTRODUCTION}

In December 2020, two mRNA vaccines against SARS-CoV-2 were authorized in Canada based upon a schedule of two doses spaced 3 weeks (BNT162b2 (Pfizer-BioNTech)) or 4 weeks (mRNA1273 (Moderna)) apart [1]. Phase III randomized-controlled trials showed vaccine efficacy that exceeded $90 \%$ for both products beginning from 14 days after a single dose but did not inform protection beyond 3-4 weeks post-vaccination [2-5]. Healthcare workers (HCWs) were amongst the first prioritized for COVID-19 vaccination and several observational studies have since reported vaccine effectiveness (VE) after a single dose but most had short follow-up periods, the longest extending 8 weeks post-vaccination [6-10].

In the context of limited vaccine supply, the Quebec Immunization Committee (QIC) recommended that the province of Quebec, Canada defer the second dose of vaccine in order to optimize first-dose coverage and provide protection to as many high-risk individuals as possible against COVID-related hospitalizations and deaths [11]. The QIC did not pre-specify the interval for second-dose administration, relying upon real-time monitoring of single-dose VE and adaptation in the event of waning protection [12]. The vaccination campaign in Quebec began December 14, 2020, and initially targeted long-term care facility (LTCF) residents and healthcare workers (HCW) with direct patient contact. On March 3, 2021, the Canadian National Advisory Committee on Immunization and the Quebec Ministry of Health set the interval between doses at 16 weeks based upon expected vaccine supply, ethical considerations and short-term but reassuring VE findings $[13,14]$. Herein, we compare one- and two-dose mRNA VE against SARS- 
medRxiv preprint doi: https://doi.org/10.1101/2021.07.19.21260445; this version posted July 22, 2021. The copyright holder for this preprint

(which was not certified by peer review) is the author/funder, who has granted medRxiv a license to display the preprint in perpetuity.

It is made available under a CC-BY-NC-ND 4.0 International license .

CoV-2, including varying outcome severity and variants of concern (VOC), among HCWs in

Quebec and assess the stability of single-dose protection across 16 weeks post-vaccination.

\section{METHODS}

\section{Study design}

The study used a test-negative design: HCWs who tested RT-PCR positive for SARS-CoV-2 during the study period were cases; HCWs who tested RT-PCR negative were controls.

The case reference date was defined hierarchically as the date of symptom onset (83.5\%) or if not available, then the date of specimen collection (16.5\%). The control reference date was defined by specimen collection date. To account for time-varying likelihoods of SARS-CoV-2 exposure and vaccination [15], a density sampling approach was used with 10 randomly-sampled controls per case matched by week of reference date. A HCW could be sampled several times as a control over the study period (but only once per week) and could subsequently be included as a case. All cases were censored at their reference date.

\section{Population}

The study population included publicly-paid HCWs but not privately-paid HCWs (in clinics, pharmacies, private seniors' residences, etc.) or physicians who are paid by the provincial Medicare system.

Participants were excluded if: they were a confirmed SARS-CoV-2 case (RT-PCR confirmed or epidemiologically-linked) before January 17, 2021; were missing a unique personal identifying number (PIN) used for data linkage; had an invalid vaccination date (before December $14^{\text {th }}$ ); or 
medRxiv preprint doi: https://doi.org/10.1101/2021.07.19.21260445; this version posted July 22, 2021. The copyright holder for this preprint

(which was not certified by peer review) is the author/funder, who has granted medRxiv a license to display the preprint in perpetuity.

It is made available under a CC-BY-NC-ND 4.0 International license .

were $<18$ or $\geq 75$ years old. HCWs in child and youth protection centers or those hired temporarily for pandemic work by Ministerial order were also excluded. Finally, AstraZeneca vaccine recipients were excluded from the date of vaccination because their limited number precluded VE estimation.

\section{Data sources}

Using the unique PIN, the cohort of all publicly-funded HCWs in the province was linked with: 1) the provincial database of all SARS-CoV-2 infections reported to public health since pandemic start, including associated clinical details collected during case investigation by public health authorities; 2) the administrative hospitalization database and the chronic disease surveillance system, which integrates information on pre-existing medical conditions; 3) the Quebec provincial immunization registry which is a census of all Quebec residents insured under the universal publicly-funded health care system, including whether or not vaccinated, vaccination

date(s) and type of vaccine received; 4) the provincial centralized laboratory database, including the dates, results and reason for all RT-PCR tests for SARS-CoV-2 across the province; and 5) variant of concern (VOC) PCR screening assay results used to identify signature mutations (69-70 deletion, N501Y, E484K) to genetically characterize and categorize viruses. VOC screening was undertaken on a convenience sample of $10 \%$ of SARS-CoV-2 positive specimens in January 2021; on nearly $100 \%$ of specimens in February and March; and on about $85 \%$ of specimens from April 2021 onwards when the VOC prevalence exceeded 90\% (Supplementary Figure 1) [16]. As of June $6,2021,89 \%$ of identified VOC cases were the Alpha variant (Pango lineage: B.1.1.7) [17]. 
medRxiv preprint doi: https://doi.org/10.1101/2021.07.19.21260445; this version posted July 22, 2021. The copyright holder for this preprint

(which was not certified by peer review) is the author/funder, who has granted medRxiv a license to display the preprint in perpetuity.

It is made available under a CC-BY-NC-ND 4.0 International license .

The study period included HCWs with specimen reference date between January 17

(epidemiological week 3) and June 5 (week 22), 2021 (Figure 1), taking into account the immunization start-date and a several-week lag for vaccine effect. Data were extracted on June $17^{\text {th }} 2021$, allowing additional 14-day lag to capture associated hospitalizations.

$\underline{\text { Vaccination and outcome definitions }}$

Vaccination status was defined in relation to the reference date. In primary analysis, a participant was deemed a single- or two-dose vaccinee if the doses were received $\geq 14$ days or $\geq 7$ days before the reference date (with day of vaccination being day 0 ), respectively, requiring $\geq 3$ weeks between doses. HCWs who received no vaccine doses at any time on or before the reference date were considered unvaccinated whereas those who received the first dose $<14$ days or second dose $<7$ days prior were excluded. RT-PCR confirmed SARS-CoV-2 outcomes of varying severity were explored, including: any infection; symptomatic infection of any severity (specified hereafter as COVID-19); and COVID-19-related hospitalization (occurring within 30 days of illness onset).

$\underline{\text { VE analysis }}$

Odds ratios $(\mathrm{OR})$ and their $95 \%$ confidence intervals $(95 \% \mathrm{Cl})$ among one- and two-dose vaccinees relative to unvaccinated HCWs were estimated by multivariate conditional logistic regression using the matching week as strata and adjusting for potential confounders. VE and $95 \% \mathrm{Cls}$ were derived as: $(1-$ ORadjusted $) \times 100$.

Adjustment variables included: age group (18-29, 30-39, 40-49, 50-59, 60-74 years); sex; healthcare setting (hospitals and local community health centers, LTCFs, rehabilitation centers, 
medRxiv preprint doi: https://doi.org/10.1101/2021.07.19.21260445; this version posted July 22, 2021. The copyright holder for this preprint (which was not certified by peer review) is the author/funder, who has granted medRxiv a license to display the preprint in perpetuity.

It is made available under a CC-BY-NC-ND 4.0 International license .

home care, other); occupation (nurse, nursing assistant, personal healthcare support worker, other technical and health assisting occupations, administrative and management staff, healthcare technician, social workers, others); region of the healthcare setting (18 in Quebec); and presence of 17 possible comorbidities associated with increased COVID-19 hospitalization risk (known for $\sim 90 \%$ of HCWs) [18].

In addition to overall primary analyses by outcome severity, sensitivity analyses included: (a) stratifying by HCW priority group based upon those targeted before January 31 (week 5) or since February 21 (week 8) reflecting higher and lower frequency of direct patient contact and baseline infection risk, respectively; (b) stratifying by VOC status; (c) restricting to HCWs with data on 17 pre-existing conditions of comorbidity (at least one, at least two or by the number of $0,1,2,3,4, \geq 5$ conditions); and (d) stratifying by reason for testing (compatible symptoms, outbreak or systematic screening).

\section{$\underline{\text { Ethical aspects }}$}

This study was conducted as a surveillance and evaluation protocol with the legal mandate of the National Director of Public Health of Quebec and with the requirement for ethics approval thereby waived under the Public Health Act. It has been approved by the Research ethics board of the CHU de Québec-Université Laval.

\section{RESULTS}

Study population 
medRxiv preprint doi: https://doi.org/10.1101/2021.07.19.21260445; this version posted July 22, 2021. The copyright holder for this preprint

(which was not certified by peer review) is the author/funder, who has granted medRxiv a license to display the preprint in perpetuity.

It is made available under a CC-BY-NC-ND 4.0 International license .

Of the 342,138 HCWs in the initial cohort, 333,832 (97.6\%) were successfully linked with the

immunization registry. As of June 5 (end of week 22), 86.0\% of individual HCWs in the cohort had received at least one vaccine dose (88.0\% Pfizer-BioNTech, 9.4\% Moderna, and 2.6\%

AstraZeneca vaccine) and 38.9\% had received two doses (Figure 1).

We excluded: $8 \%$ of HCWs who were confirmed COVID-19 cases before January 17, 2021; 4\%

who worked in child and youth protection centers; 3\% with missing PIN; $1 \%$ temporarily hired by

Ministerial order; and $<1 \%$ with an invalid vaccination date. Among the 284,637 remaining

HCWs, 115,288 had no testing during the study period leaving 169,349 HCWs with 548,796

specimens for VE analysis. There were 5,316 cases with 53,160 controls randomly-sampled

among negative tests (Supplementary Figure S1), of which $10.8 \%$ cases and $11.8 \%$ controls

vaccinated 0-13 days or 0-6 days before the first or second dose, respectively, were excluded

from primary analyses.

\section{Characteristics of cases and controls}

At their reference date, $23.8 \%$ of cases and $49.1 \%$ of controls had received one dose $\geq 14$ days earlier and $0.9 \%$ of cases and $3.9 \%$ of controls had received two doses $\geq 7$ days earlier. The percentage of controls vaccinated with at least one dose $\geq 14$ days before the reference date increased with age, from $49.1 \%$ in 18 -29-year-olds to $61.5 \%$ among 60 -74-year-olds

(Supplementary Figure S2). For those who received 2 doses, the median interval between doses was nearly 16 weeks (111 days for cases and 112 days for controls). The median follow-up time for one-dose vaccinees was 56 days and for two-dose vaccinees was 18 days. Among all cases, 80.5\% had COVID-19-related symptoms, 1.7\% were hospitalized and one unvaccinated HCW died 
medRxiv preprint doi: https://doi.org/10.1101/2021.07.19.21260445; this version posted July 22, 2021. The copyright holder for this preprint (which was not certified by peer review) is the author/funder, who has granted medRxiv a license to display the preprint in perpetuity.

It is made available under a CC-BY-NC-ND 4.0 International license .

(Table 1). For symptomatic COVID-19 cases, the median and mean interval between symptom onset and testing was 1.0 and 1.3 days, respectively.

Screening PCR tests to identify VOC were performed on 2889 (54.4\%) positive specimens (91.5\% during weeks 8 to 20): 1620 (56.1\%) were a VOC and among them 73.0\% were identified as the Alpha variant (Table 1).

Demographic and employment characteristics are provided in detail in Table 1.

$\underline{\text { Vaccine effectiveness }}$

Overall, by outcome severity

The overall adjusted single-dose mRNA VE was 70.4\% (95\%Cl: 68.2-72.5) against any SARS-CoV-2 infection, $72.9 \%(95 \% \mathrm{Cl}$ : 70.6-75.0) against COVID-19 and 97.2\% (95\%Cl: 92.3-99.0) against COVID-19-related hospitalization (Table 2). The overall adjusted two-dose mRNA VE was 85.8\% (95\%Cl: 81.0-89.50) and 92.7\% (95\%Cl: 88.5-95.4), respectively, with no associated hospitalizations. No differences were found by vaccine type (Pfizer-BioNTech or Moderna) (Table 2) or by age group (Supplementary Figure S2).

One-dose VE against COVID-19 was 76-78\% between 2- and 7-weeks post-vaccination, declining slightly to about $70 \%$ between 9 - and 16 -weeks post-vaccination $(<1 \%$ were vaccinated $>16$ weeks prior) (Figure 2). Follow- up after two doses was too short for corresponding interval analyses.

By HCW priority group 
medRxiv preprint doi: https://doi.org/10.1101/2021.07.19.21260445; this version posted July 22, 2021. The copyright holder for this preprint

(which was not certified by peer review) is the author/funder, who has granted medRxiv a license to display the preprint in perpetuity.

It is made available under a CC-BY-NC-ND 4.0 International license .

Among HCWs first targeted for vaccination before week 5 (because of highest likelihood of direct patient contact and baseline infection risk), VE during the period 0-13 days after the first dose (when no vaccine effect is expected) was highly negative $(-101.6 \%, 95 \% \mathrm{Cl}:-139.9$ to -69.5$)$. Conversely, among HCWs first vaccinated after week 8 (at lower baseline infection risk), VE during the period 0-13 days was significantly higher at $43.7 \%(95 \% \mathrm{Cl}: 31.9-53.5)$. Thereafter, the earlier vs. later targeted HCWs had lower VE overall across the 2-16-week analysis period (52.2\%, 95\% Cl: 47.1-56.9 vs $77.4 \%, 95 \% \mathrm{Cl}: 73.0-81.1)$, with neither target group showing decline in protection over that extended follow-up period (Supplementary Table S1 and Figure 3).

\section{By VOC status}

With restriction to cases with screening VOC results, VE against COVID-19 was higher for nonVOC than VOC among single-dose $(77.0 \%, 95 \% \mathrm{Cl}$ : $72.6-80.7$ versus $62.5 \%, 95 \% \mathrm{Cl}: 57.4-67.0)$ but not two-dose recipients (86.5\%, 95\% Cl: 56.8-95.8 versus 93.5\%, 95\% Cl: 88.7-96.3). The Alphaspecific VE did not differ from VE against any VOC (including those with undetermined lineage) (Table 2) but was consistently lower than for non-VOC across the entire follow-up period (Figure 4). Among 90 hospitalized cases, 63 were analysed for VOC with the only vaccinated case bearing the Alpha variant.

By comorbidity and testing indication

Adjustment for the presence of comorbidity did not meaningfully affect VE estimates (data not shown). In analyses stratified by testing indication, one-dose VE was lower for COVID-19 compatible symptoms (62.7\%, 95\%Cl: 58.6-66.4) versus outbreak- $(73.0 \%, 95 \% \mathrm{Cl}$ : $64.7-79.4)$ or 
medRxiv preprint doi: https://doi.org/10.1101/2021.07.19.21260445; this version posted July 22, 2021. The copyright holder for this preprint

(which was not certified by peer review) is the author/funder, who has granted medRxiv a license to display the preprint in perpetuity.

It is made available under a CC-BY-NC-ND 4.0 International license .

screening-related testing (73.1\%, 95\% Cl: 64.9-79.4). Two-dose estimates were higher for HCWs

tested for symptomatic illness but with overlapping 95\%Cls (Supplementary Table S1).

\section{DISCUSSION}

In this observational study, we report single-dose mRNA VE of 70\% against any SARS-CoV-2

infection and 73\% against COVID-19 illness among HCWs in Quebec, Canada. Although VE was higher at $86 \%$ and 93\%, respectively, after a second dose, VE against COVID-19 hospitalization was comparably high at $>95 \%$ for both one- and two-dose recipients. Importantly, we provide the longest single-dose vaccination follow-up to date, showing substantial protection maintained for at least 16 weeks after receipt of just one dose of mRNA vaccine. Overall, our findings reinforce the recommendation for second-dose deferral and show that the interval between doses can be extended to at least four months where indicated due to scarce vaccine supply.

Other observational studies from the US, Israel and Europe have reported comparable PfizerBioNTech VE among HCWs beginning 14 and 7 days after dose one or two, respectively, but these involved only short follow-up periods. In two US studies, single-dose VE among HCWs, vaccinated according to the manufacturer's schedule, was $78 \%$ against any infection [6], and $74 \%$ against symptomatic infection [7], with two dose VE of $97 \%$ and $94 \%$, respectively $[6,7]$. Similarly, in an Israeli HCW cohort, single-dose VE was 75\% against any SARS-CoV-2 infection from 15-28 days post-vaccination [9]. In Italy, single-dose VE between 14-21 days postvaccination in $\mathrm{HCW}$ s was $83 \%$ against symptomatic infection and lower at $66 \%$ for $\geq 21$ days without specification of the longest duration of follow-up [8]. In the UK, where the second dose was also deferred [19], the SIREN study reported VE against any SARS-CoV-2 infection of 72\% 
medRxiv preprint doi: https://doi.org/10.1101/2021.07.19.21260445; this version posted July 22, 2021. The copyright holder for this preprint (which was not certified by peer review) is the author/funder, who has granted medRxiv a license to display the preprint in perpetuity.

It is made available under a CC-BY-NC-ND 4.0 International license .

from 21 to 69 days post-vaccination in HCWs systematically tested over a maximum of 8 weeks [10].

In our study, single-dose mRNA VE against hospitalization among HCWs was 97\% across a 16week period. Although evidence elsewhere supports high two-dose protection against hospitalization [20-22], few studies to date have reported single-dose protection and none over such an extended follow up period. In population-based studies, one-dose VE against hospitalizations among mostly older adults was 74\% (14-20 days post-vaccination) in Israel, 77\% (>14 days post-vaccination) in the US and 91\% (14-34 days post-vaccination) in Scotland [21-23].

The Alpha (B.1.1.7) variant was the most prevalent SARS-CoV-2 virus in circulation in Quebec between late March and the end of our study period. The lower single-dose VE of $60 \%(95 \% \mathrm{Cl}$ : $54 \%$ to $66 \%$ ) we report against symptomatic Alpha infection among HCWs is consistent with the lower single-dose VE of $67 \%$ against Alpha infection recently reported for older adults $\geq 70$ years old from the province of British Columbia, Canada also based upon test-negative design [24]. Our higher two-dose estimate of $93 \%(95 \% \mathrm{Cl}: 87 \%$ to $96 \%)$ is also consistent with estimates exceeding 90\% from Israel [20] and Qatar [25]. Of note, the later predominant contribution by and lower VE against the Alpha variant, whose prevalence among SARS-CoV-2 infections was $<30 \%$ in mid-March (week 12) but increased to $>90 \%$ at the end of the study, may have contributed to an apparent but perhaps artefactual decline in overall single-dose protection across the analysis period.

Furthermore, with respect to the question of potential waning of single-dose vaccine protection, we highlight an important methodological issue, critical for other investigators to consider. In 
medRxiv preprint doi: https://doi.org/10.1101/2021.07.19.21260445; this version posted July 22, 2021. The copyright holder for this preprint

(which was not certified by peer review) is the author/funder, who has granted medRxiv a license to display the preprint in perpetuity.

It is made available under a CC-BY-NC-ND 4.0 International license .

particular, we illustrate the impact that confounding by indication can have when averaging VE across sub-groups with different exposure risks and who are sequentially prioritized or targeted for vaccination on that basis. HCWs earliest prioritized for vaccination because of highest baseline infection risk will also contribute most to the longest post-vaccination analysis intervals. In pooled analysis, their systematically higher infection risk and lower VE will lead to an overall, but erroneous, impression of declining single-dose VE generally with time since vaccination. Conversely, with appropriate stratification based upon underlying differential in exposure and infection risk, we show single-dose VE to have been stable across the analysis period including both earlier and later prioritized HCW sub-sets. Properly addressing that methodological bias, we demonstrate no evidence for decrease in single-dose VE across a four-month follow-up period.

This study has limitations, foremost related to its observational design, subject to bias and confounding, and reliance on surveillance data subject to misclassification and missing information. Like others we could not fully adjust for differential exposure risk or fully ascertain the symptom profile notably after specimen testing. Despite easy access to testing, some asymptomatic infections were likely missed. HCWs with undetected infections before the study period could not be excluded leading to bias due to undiagnosed cases among vaccinated (overestimation) or unvaccinated (underestimation) participants [26]. A Ministerial order issued on April 9 requiring unvaccinated HCWs to be systematically tested every 3 days [27] may have increased detection of asymptomatic infections in unvaccinated individuals potentially leading to overestimation of VE against any infection at the end of the follow-up period but without affecting VE against COVID-19 or hospitalization. HCWs are active and relatively young adults and these results may not apply to older adults [28,29]. Even if adjustment for comorbidities did not 
medRxiv preprint doi: https://doi.org/10.1101/2021.07.19.21260445; this version posted July 22, 2021. The copyright holder for this preprint

(which was not certified by peer review) is the author/funder, who has granted medRxiv a license to display the preprint in perpetuity.

It is made available under a CC-BY-NC-ND 4.0 International license .

change VE estimates, HCWs with medical conditions at high risk of severe disease were

frequently removed from direct patient care duties during the pandemic and their VE might be lower than the estimates for all HCWs [22]. Despite these limitations, our study has strengths including its extended post-single-dose follow-up of a large and well-defined cohort and its several sensitivity and stratified analyses to address confounding due to time-dependent variables (vaccination prioritization and exposure risk) and variation in VOC circulation. Whereas VE estimates from our observational design may not precisely mimic short-term RCT estimates, the stable pattern of persistent single-dose protection we report across several months of follow-up is a unique and informative advantage over prior studies and may be the most meaningful with respect to public health implications for other areas still grappling with vaccine shortage.

In conclusion, one dose of mRNA vaccine reduced the risk of COVID-19 among HCWs by at least three-quarters (preventing three out of four symptomatic infections) and the associated risk of hospitalization by more than 95\%, with such single-dose protection extending at least 16 weeks post-vaccination. Our findings of substantial and sustained single-dose VE, including against the Alpha variant, reinforce the option to defer the second dose of mRNA vaccine in circumstances of scarce vaccine supply and where broad single-dose coverage is critically needed.

\section{Funding}

This work was supported by the Ministère de la santé et des services sociaux du Québec.

\section{Potential conflicts of interest}


medRxiv preprint doi: https://doi.org/10.1101/2021.07.19.21260445; this version posted July 22, 2021. The copyright holder for this preprint

(which was not certified by peer review) is the author/funder, who has granted medRxiv a license to display the preprint in perpetuity.

It is made available under a CC-BY-NC-ND 4.0 International license.

DT is supported by a career award from the Fonds de recherche du Québec - Santé. GDS

received a grant from Pfizer for anti-meningococcal immunogenicity study.

\section{Acknowledgments}

We would like to thank Louis Rochette for his work on preparing the healthcare workers' dataset.

\section{REFERENCES}

1. National Advisory Committee on Immunization (NACl). Recommendations on the use of

COVID-19 Vaccines. Ottawa: NACl. Available at: https://www.canada.ca/content/dam/phacaspc/documents/services/immunization/national-advisory-committee-on-immunizationnaci/recommendations-use-covid-19-vaccines/recommendations-use-covid-19-vaccinesen.pdf. Accessed 10 June 2021.

2. Polack FP, Thomas SJ, Kitchin N, et al. Safety and Efficacy of the BNT162b2 mRNA Covid-19

Vaccine. N Engl J Med, 2020; 383:2603-2615.

3. Baden LR, El Sahly HM, Essink B, et al. Efficacy and Safety of the mRNA-1273 SARS-CoV-2 Vaccine. N Engl J Med, 2021; 384:403-416.

4. Skowronski DM, De Serres G. Safety and Efficacy of the BNT162b2 mRNA Covid-19 Vaccine. N Engl J Med, 2021; 384:1576-1577. 
medRxiv preprint doi: https://doi.org/10.1101/2021.07.19.21260445; this version posted July 22, 2021. The copyright holder for this preprint

(which was not certified by peer review) is the author/funder, who has granted medRxiv a license to display the preprint in perpetuity.

It is made available under a CC-BY-NC-ND 4.0 International license .

5. Moderna COVID-19 Vaccine. FDA Briefing Document. Vaccines and Related Biological

Products Advisory Committee Meeting. December 17, 2020. 2020. Available at:

https://www.fda.gov/media/144434/download. Accessed 10 June 2021.

6. Pilishvili T, Fleming-Dutra KE, Farrar JL, et al. Interim Estimates of Vaccine Effectiveness of Pfizer-BioNTech and Moderna COVID-19 Vaccines Among Health Care Personnel - 33 U.S. Sites, January-March 2021. MMWR Morb Mortal Wkly Rep, 2021; 70:753-758.

7. Swift MD, Breeher LE, Tande AJ, et al. Effectiveness of mRNA COVID-19 vaccines against SARS-CoV-2 infection in a cohort of healthcare personnel. Clinical Infectious Diseases, 2021; :ciab361.

8. Fabiani M, Ramigni M, Gobbetto V, Mateo-Urdiales A, Pezzotti P, Piovesan C. Effectiveness of the Comirnaty (BNT162b2, BioNTech/Pfizer) vaccine in preventing SARS-CoV-2 infection among healthcare workers, Treviso province, Veneto region, Italy, 27 December 2020 to 24 March 2021. Eurosurveillance, 2021; 26.

9. Amit S, Beni SA, Biber A, Grinberg A, Leshem E, Regev-Yochay G. Postvaccination COVID-19 among Healthcare Workers, Israel. Emerg Infect Dis, 2021; 27:1220-1222.

10. Hall VJ, Foulkes S, Saei A, et al. COVID-19 vaccine coverage in health-care workers in England and effectiveness of BNT162b2 mRNA vaccine against infection (SIREN): a prospective, multicentre, cohort study. The Lancet, 2021; 397:1725-1735.

11. Comité sur l'immunization du Québec. Stratégie de vaccination contre la COVID-19 : report de la 2e dose en contexte de pénurie. Available at: 
medRxiv preprint doi: https://doi.org/10.1101/2021.07.19.21260445; this version posted July 22, 2021. The copyright holder for this preprint

(which was not certified by peer review) is the author/funder, who has granted medRxiv a license to display the preprint in perpetuity.

It is made available under a CC-BY-NC-ND 4.0 International license .

https://www.inspq.qc.ca/publications/3098-strategie-vaccination-2e-dose-covid. Accessed

10 June 2021.

12. Comité sur l'immunization du Québec. Demande complémentaire pour l'avis Stratégie de vaccination contre la COVID-19 : report de la 2e dose en contexte de pénurie. Available at:

https://www.inspq.qc.ca/publications/3103-vaccination-2e-dose-contexte-penurie-covid19.

Accessed 10 June 2021.

13. National Advisory Committee on Immunization (NACl). NACl rapid response: Extended dose intervals for COVID-19 vaccines to optimize early vaccine rollout and population protection in Canada. Available at: https://www.canada.ca/en/publichealth/services/immunization/national-advisory-committee-on-immunizationnaci/extended-dose-intervals-covid-19-vaccines-early-rollout-population-protection.html. Accessed 10 June 2021.

14. Ministère de la Santé et des Services Sociaux. Pandémie de la COVID-19 - Un intervalle de 16 semaines entre les deux doses de vaccin. Available at: https://www.msss.gouv.qc.ca/ministere/salle-de-presse/communique-2676/. Accessed 10 June 2021.

15. Rothman KJ, Greenland S, Lash TL. Modern Epidemiology. Third edition. Lippincott Williams \& Wilkins, 2008. 
medRxiv preprint doi: https://doi.org/10.1101/2021.07.19.21260445; this version posted July 22, 2021. The copyright holder for this preprint

(which was not certified by peer review) is the author/funder, who has granted medRxiv a license to display the preprint in perpetuity.

It is made available under a CC-BY-NC-ND 4.0 International license .

16. Institut national de santé publique du Québec. Données sur les variants du SRAS-CoV-2 au Québec. Available at: https://www.inspq.qc.ca/covid-19/donnees/variants. Accessed 5 July 2021.

17. National Collaborating Centre for Infectious Diseases. Updates on COVID-19 Variants of Concern. Available at: https://nccid.ca/covid-19-variants/. Accessed 10 June 2021.

18. Simard M, de Montigny C, Sonia J, Fortin E. Impact of comorbidities on the risk of death and hospitalization among confirmed cases of COVID-19 during the first months of the pandemic in Québec. Institut national de santé publique du Québec, 2020. Available at: https://www.inspq.qc.ca/sites/default/files/publications/3082-impact-comorbidities-riskdeath-covid-19.pdf. Accessed 10 June 2021.

19. Iacobucci G, Mahase E. Covid-19 vaccination: What's the evidence for extending the dosing interval? BMJ, 2021; :n18.

20. Haas EJ, Angulo FJ, McLaughlin JM, et al. Impact and effectiveness of mRNA BNT162b2 vaccine against SARS-CoV-2 infections and COVID-19 cases, hospitalisations, and deaths following a nationwide vaccination campaign in Israel: an observational study using national surveillance data. The Lancet, 2021; 397:1819-1829.

21. Vahidy FS, Pischel L, Tano ME, et al. Real World Effectiveness of COVID-19 mRNA Vaccines against Hospitalizations and Deaths in the United States. MedRxiv 21255873 [Preprint]. 2021. Available at: http://medrxiv.org/lookup/doi/10.1101/2021.04.21.21255873. Accessed 16 June 2021. 
medRxiv preprint doi: https://doi.org/10.1101/2021.07.19.21260445; this version posted July 22, 2021. The copyright holder for this preprint

(which was not certified by peer review) is the author/funder, who has granted medRxiv a license to display the preprint in perpetuity.

It is made available under a CC-BY-NC-ND 4.0 International license .

22. Dagan N, Barda N, Kepten E, et al. BNT162b2 mRNA Covid-19 Vaccine in a Nationwide Mass Vaccination Setting. N Engl J Med, 2021; 384:1412-1423.

23. Vasileiou E, Simpson CR, Robertson C, et al. Effectiveness of First Dose of COVID-19 Vaccines Against Hospital Admissions in Scotland: National Prospective Cohort Study of 5.4 Million People. SSRN Journal, 2021.

24. Skowronski DM, Setayeshgar S, Zou M, et al. Single-dose mRNA vaccine effectiveness against SARS-CoV-2, including Alpha and Gamma variants: a test-negative design in adults 70 years and older in British Columbia, Canada. Clinical Infectious Diseases, 2021; :ciab616.

25. Abu-Raddad LJ, Chemaitelly H, Butt AA. Effectiveness of the BNT162b2 Covid-19 Vaccine against the B.1.1.7 and B.1.351 Variants. N Engl J Med, 2021; 385:187-189.

26. Krammer F, Srivastava K, Alshammary H, et al. Antibody Responses in Seropositive Persons after a Single Dose of SARS-CoV-2 mRNA Vaccine. N Engl J Med, 2021; 384:1372-1374.

27. Ministère de la Santé et des Services Sociaux du Québec. Arrêté numéro 2021-024 du ministre de la Santé et des Services sociaux en date du 9 avril 2021. Available at: https://cdn-contenu.quebec.ca/cdn-contenu/adm/min/sante-services-sociaux/publicationsadm/lois-reglements/AM_2021-024.pdf?1618075211. Accessed 10 June 2021.

28. Lopez Bernal J, Andrews N, Gower C, et al. Early effectiveness of COVID-19 vaccination with BNT162b2 mRNA vaccine and ChAdOx1 adenovirus vector vaccine on symptomatic disease, hospitalisations and mortality in older adults in England. MedRxiv 21252652 [Preprint]. 
medRxiv preprint doi: https://doi.org/10.1101/2021.07.19.21260445; this version posted July 22, 2021. The copyright holder for this preprint (which was not certified by peer review) is the author/funder, who has granted medRxiv a license to display the preprint in perpetuity. It is made available under a CC-BY-NC-ND 4.0 International license.

2021. Available at: http://medrxiv.org/lookup/doi/10.1101/2021.03.01.21252652. Accessed

10 July 2021.

29. Hyams C, Marlow R, Maseko Z, et al. Assessing the Effectiveness of BNT162b2 and ChAdOx1nCoV-19 COVID-19 Vaccination in Prevention of Hospitalisations in Elderly and Frail Adults: A Single Centre Test Negative Case-Control Study. SSRN Journal, 2021; 


\section{Tables}

Table 1. Vaccination status, demographic and employment characteristics of cases and controls

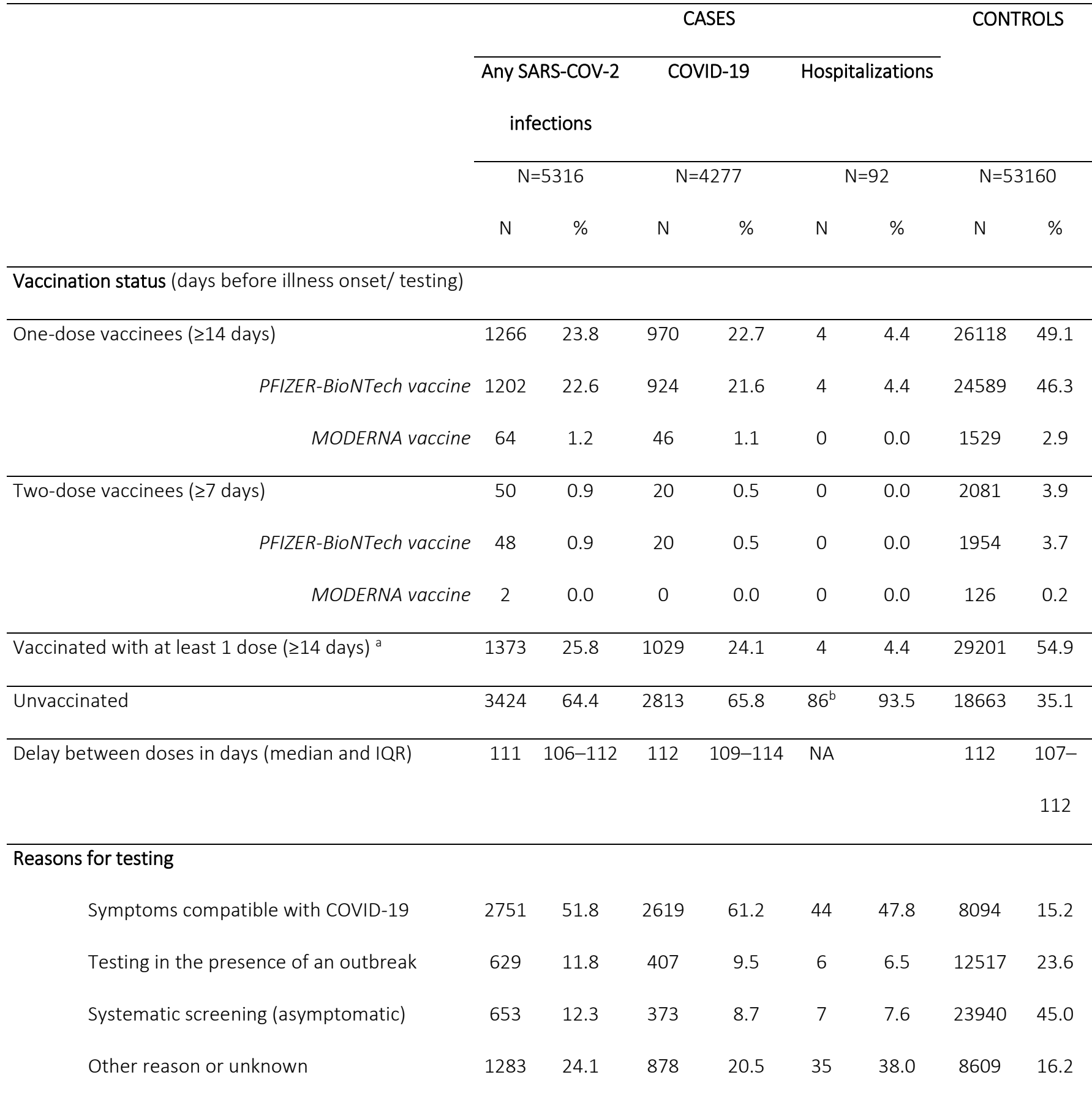

Variants of concern (among 2889 positive specimens) 
medRxiv preprint doi: https://doi.org/10.1101/2021.07.19.21260445; this version posted July 22, 2021. The copyright holder for this preprint (which was not certified by peer review) is the author/funder, who has granted medRxiv a license to display the preprint in perpetuity.

It is made available under a CC-BY-NC-ND 4.0 International license .

$\begin{array}{llllllll}\text { Alpha variant (lineage B.1.1.7) } & 1182 & 40.9 & 1003 & 42.6 & 31 & 48.4 & \text { NA }\end{array}$

$\begin{array}{lllllllll}\text { VOC not detected } & 944 & 32.7 & 784 & 33.3 & 15 & 23.4 & \text { NA }\end{array}$

$\begin{array}{lllllllll}\text { Uninterpretable result } & 325 & 11.2 & 203 & 8.6 & 6 & 9.4 & \text { NA }\end{array}$

Demographic, clinical and employment characteristics

\begin{tabular}{|c|c|c|c|c|c|c|c|c|}
\hline Age (median and IQR) & 39 & $30-49$ & 39 & $30-49$ & 48.5 & $38-56$ & 41 & $31-51$ \\
\hline $18-29$ years & 1295 & 24.4 & 1049 & 24.5 & 9 & 9.8 & 10826 & 20.4 \\
\hline 30-39 years & 1403 & 26.4 & 1157 & 27.1 & 17 & 18.5 & 13642 & 25.7 \\
\hline $40-49$ years & 1343 & 25.3 & 1067 & 25.0 & 24 & 26.1 & 13569 & 25.5 \\
\hline $50-59$ years & 1049 & 19.7 & 828 & 19.4 & 31 & 33.7 & 11957 & 22.5 \\
\hline $60-74$ years & 226 & 4.3 & 176 & 4.1 & 11 & 12.0 & 3166 & 6.0 \\
\hline Sex, female & 4233 & 79.6 & 3459 & 80.9 & 69 & 75.0 & 44280 & 83.3 \\
\hline \multicolumn{9}{|l|}{ Comorbidity $(\mathrm{n}=53075 ; 90.8 \%)^{c}$} \\
\hline At least one medical condition & 1617 & 30.8 & 1302 & 30.6 & 49 & 53.3 & 15963 & 33.1 \\
\hline At least two medical conditions & 502 & 9.5 & 415 & 9.8 & 21 & 22.8 & 4845 & 10.1 \\
\hline \multicolumn{9}{|l|}{ Job category } \\
\hline Nurse & 975 & 18.3 & 801 & 18.7 & 16 & 17.4 & 12519 & 23.6 \\
\hline Nursing assistant & 474 & 8.9 & 372 & 8.7 & 12 & 13.0 & 4516 & 8.5 \\
\hline Healthcare support worker & 1108 & 20.8 & 817 & 19.1 & 29 & 1.1 & 12357 & 23.2 \\
\hline Other health assisting occupations & 662 & 12.5 & 503 & 11.8 & 10 & 31.5 & 5430 & 10.2 \\
\hline Technical assisting occupations & 424 & 8.0 & 337 & 7.9 & 3 & 10.9 & 3154 & 5.9 \\
\hline Administrative and management staff & 849 & 16.0 & 739 & 17.3 & 15 & 3.3 & 5305 & 10.0 \\
\hline Healthcare technician & 349 & 6.6 & 289 & 6.8 & 4 & 16.3 & 5084 & 9.6 \\
\hline Social worker & 402 & 7.6 & 360 & 8.4 & 2 & 4.4 & 3200 & 6.0 \\
\hline Other & 73 & 1.4 & 59 & 1.4 & 1 & 2.2 & 1595 & 3.0 \\
\hline
\end{tabular}

Facility

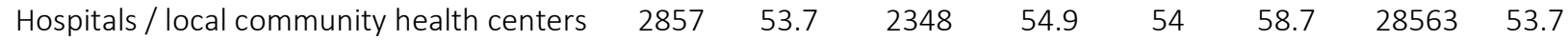


medRxiv preprint doi: https://doi.org/10.1101/2021.07.19.21260445; this version posted July 22, 2021. The copyright holder for this preprint (which was not certified by peer review) is the author/funder, who has granted medRxiv a license to display the preprint in perpetuity.

\section{It is made available under a CC-BY-NC-ND 4.0 International license.}

$\begin{array}{lcccccccc}\text { Long term health facilities } & 1063 & 20.0 & 772 & 18.1 & 21 & 22.8 & 14890 & 28.0 \\ \text { Rehabilitation centers } & 283 & 5.3 & 229 & 5.4 & 1 & 1.1 & 1353 & 2.6 \\ \text { Home care } & 283 & 5.3 & 235 & 5.5 & 1 & 1.1 & 3029 & 5.7 \\ \text { Other } & 830 & 15.6 & 693 & 16.2 & 15 & 16.3 & 5325 & 10.0 \\ & & & & & & & & \end{array}$

a Including those vaccinated with 2 doses less than 7 days before the reference date

b 2 hospitalized cases were vaccinated 0-13 days before illness onset

c 17 medical conditions considered: hypertension, cardiovascular disease, neurological disorder, anemia, respiratory disease,

diabetes, hypothyroidism, fluid and electrolyte disorder, cancer, kidney disease, obesity, psychosis, liver disease, immune

disease, coagulopathy and paralysis

Abbreviations: IQR=Interquartile range; $N A=$ not applicable; VOC=Variant of concern 
medRxiv preprint doi: https://doi.org/10.1101/2021.07.19.21260445; this version posted July 22, 2021. The copyright holder for this preprint (which was not certified by peer review) is the author/funder, who has granted medRxiv a license to display the preprint in perpetuity.

It is made available under a CC-BY-NC-ND 4.0 International license .

Table 2. Overall vaccine effectiveness by outcome severity (SARS-CoV-2 infection, COVID-19 and COVID-19-related hospitalization) and by variant of concern status

\begin{tabular}{|c|c|c|c|c|c|c|}
\hline & \multicolumn{6}{|c|}{ Model adjusted } \\
\hline & \multirow[b]{3}{*}{ Cases (\%) } & \multirow[b]{3}{*}{ Controls (\%) } & \multirow{2}{*}{\multicolumn{2}{|c|}{$\begin{array}{l}\text { (stratified) for the } \\
\text { matching week }\end{array}$}} & \multirow{2}{*}{\multicolumn{2}{|c|}{ Model fully adjusted ${ }^{a}$}} \\
\hline & & & & & & \\
\hline & & & VE & $95 \% \mathrm{Cl}$ & VE & $95 \% \mathrm{Cl}$ \\
\hline \multicolumn{7}{|l|}{ Overall, by outcome severity } \\
\hline \multicolumn{7}{|c|}{ 1. VE against any SARS-CoV-2 infection } \\
\hline One-dose vaccinees ( $\geq 14$ days) & $1266(26.7)$ & $26118(55.7)$ & $74.7 \%$ & $72.9-76.4$ & $70.4 \%$ & $68.2-72.5$ \\
\hline PFIZER-BioNTech vaccine & $1202(25.7)$ & $24589(54.4)$ & $74.5 \%$ & $72.6-76.2$ & $70.3 \%$ & $68.1-72.4$ \\
\hline MODERNA vaccine & $64(1.8)$ & $1529(7.5)$ & $78.0 \%$ & $71.6-82.9$ & $68.7 \%$ & $59.5-75.9$ \\
\hline Two-doses vaccinees ( $\geq 7$ days) & $50(1.0)$ & $2081(4.4)$ & $89.3 \%$ & $85.6-92.0$ & $85.8 \%$ & $81.0-89.5$ \\
\hline PFIZER-BioNTech vaccine & $48(1.0)$ & $1954(4.3)$ & $89.0 \%$ & $85.2-91.8$ & $85.5 \%$ & $80.4-89.3$ \\
\hline MODERNA vaccine & $2(0.1)$ & $126(0.6)$ & $90.4 \%$ & $61.2-97.6$ & $84.1 \%$ & $34.9-96.1$ \\
\hline Unvaccinated & $3424(72.2)$ & $18663(39.8)$ & & & & \\
\hline \multicolumn{7}{|l|}{ 2. VE against COVID-19 } \\
\hline One-dose vaccinees ( $\geq 14$ days) & $970(25.5)$ & $26118(55.7)$ & $76.7 \%$ & $74.9-78.5$ & $72.9 \%$ & $70.6-75.0$ \\
\hline PFIZER-BioNTech vaccine & $924(24.6)$ & $24589(54.4)$ & $76.4 \%$ & $74.5-78.2$ & $72.8 \%$ & $70.5-74.9$ \\
\hline MODERNA vaccine & $46(1.6)$ & $1529(7.5)$ & $80.9 \%$ & $74.3-85.8$ & $80.9 \%$ & $74.3-85.8$ \\
\hline Two-doses vaccinees ( $\geq 7$ days) & $20(0.5)$ & $2081(4.4)$ & $94.4 \%$ & $91.3-96.5$ & $92.7 \%$ & $88.5-95.4$ \\
\hline PFIZER-BioNTech vaccine & $20(0.5)$ & $1954(4.3)$ & $94.0 \%$ & $90.7-96.2$ & $92.2 \%$ & $87.8-95.1$ \\
\hline MODERNA vaccine & $0(0)$ & $126(0.6)$ & $100 \%$ & NE & NE & NE \\
\hline Unvaccinated & $2813(74.0)$ & $18663(39.8)$ & & & & \\
\hline
\end{tabular}

\section{VE against COVID-19-related hospitalisation}

One-dose vaccinees ( $\geq 14$ days) $\quad 4(4.4) \quad 26118(55.7) \quad 97.1 \% \quad 92.0-98.9 \quad 97.2 \% \quad 92.3-99.0$


medRxiv preprint doi: https://doi.org/10.1101/2021.07.19.21260445; this version posted July 22, 2021. The copyright holder for this preprint (which was not certified by peer review) is the author/funder, who has granted medRxiv a license to display the preprint in perpetuity.

It is made available under a CC-BY-NC-ND 4.0 International license .

Two-doses vaccinees ( $\geq 7$ days) $\quad 0(0.0)$

$2081(4.4) \quad 100 \%$

NE

NE

NE

Unvaccinated $\quad 86(96.6) \quad 18663(39.8)$

\section{By VOC status}

\section{Any VOC detected}

\begin{tabular}{|c|c|c|c|c|c|c|}
\hline One-dose vaccinees ( $\geq 14$ days) & $454(36.3)$ & $26118(55.7)$ & $67.4 \%$ & $63.2-71.1$ & $62.5 \%$ & $57.4-67.0$ \\
\hline Two-doses vaccinees ( $\geq 7$ days) & $13(1.0)$ & $2081(4.4)$ & $94.8 \%$ & $90.8-97.0$ & $93.5 \%$ & $88.7-96.3$ \\
\hline Unvaccinated & $784(62.7)$ & $18663(39.8)$ & & & & \\
\hline
\end{tabular}

\section{Alpha variant}

\begin{tabular}{|c|c|c|c|c|c|c|}
\hline One-dose vaccinees ( $\geq 14$ days) & $337(37.4)$ & $26118(55.7)$ & $63.9 \%$ & $58.5-68.7$ & $60.0 \%$ & $53.6-65.5$ \\
\hline Two-doses vaccinees ( $\geq 7$ days) & $13(1.4)$ & $2081(4.4)$ & $94.0 \%$ & $89.5-96.6$ & $92.6 \%$ & $87.1-95.8$ \\
\hline Unvaccinated & $551(61.2)$ & $18663(39.8)$ & & & & \\
\hline
\end{tabular}

\section{VOC not detected}

\begin{tabular}{|c|c|c|c|c|c|c|}
\hline One-dose vaccinees ( $\geq 14$ days) & $187(25.2)$ & $26118(55.7)$ & $81.4 \%$ & $77.9-84.3$ & $77.0 \%$ & $72.6-80.7$ \\
\hline Two-doses vaccinees ( $\geq 7$ days) & $3(0.4)$ & $2081(4.4)$ & $90.2 \%$ & $68.6-97.0$ & $86.5 \%$ & $56.8-95.8$ \\
\hline Unvaccinated & $552(74.4)$ & $18663(39.8)$ & & & & \\
\hline
\end{tabular}

a Conditional logistic regression model adjusted for age, sex, job category, type of facility, health region and matching week

Abbreviations: $\mathrm{Cl}=$ confidence interval; $\mathrm{NE}=$ not estimable; $\mathrm{VE}=$ vaccine effectiveness; $\mathrm{VOC}=$ variants of concern 
medRxiv preprint doi: https://doi.org/10.1101/2021.07.19.21260445; this version posted July 22, 2021. The copyright holder for this preprint (which was not certified by peer review) is the author/funder, who has granted medRxiv a license to display the preprint in perpetuity.

It is made available under a CC-BY-NC-ND 4.0 International license .

Figure 1. Vaccination coverage in the cohort of healthcare workers and total number of reported COVID-19 cases in the population per week, Quebec, Canada.

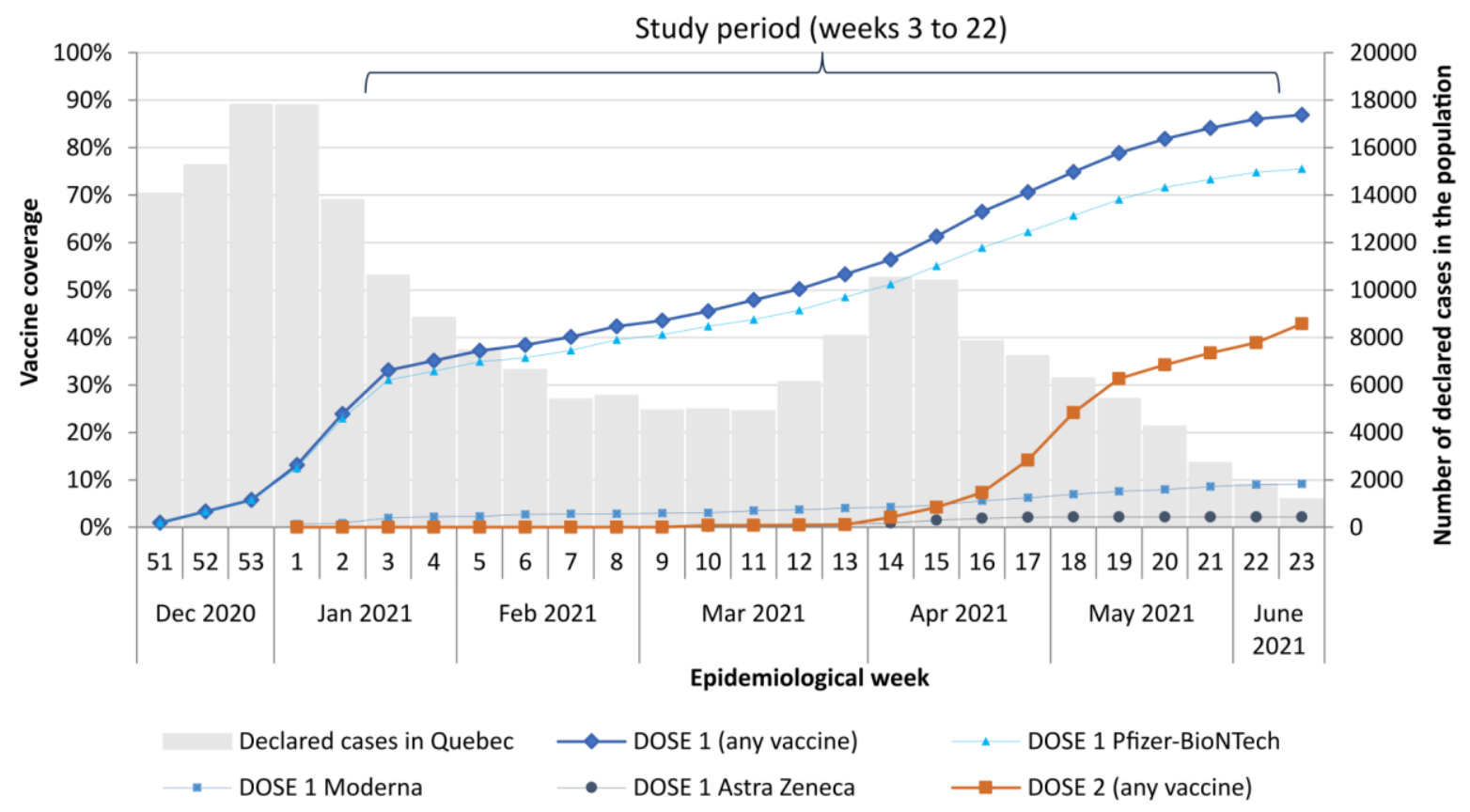

Figure 2. Vaccine effectiveness against COVID-19 by interval since vaccination

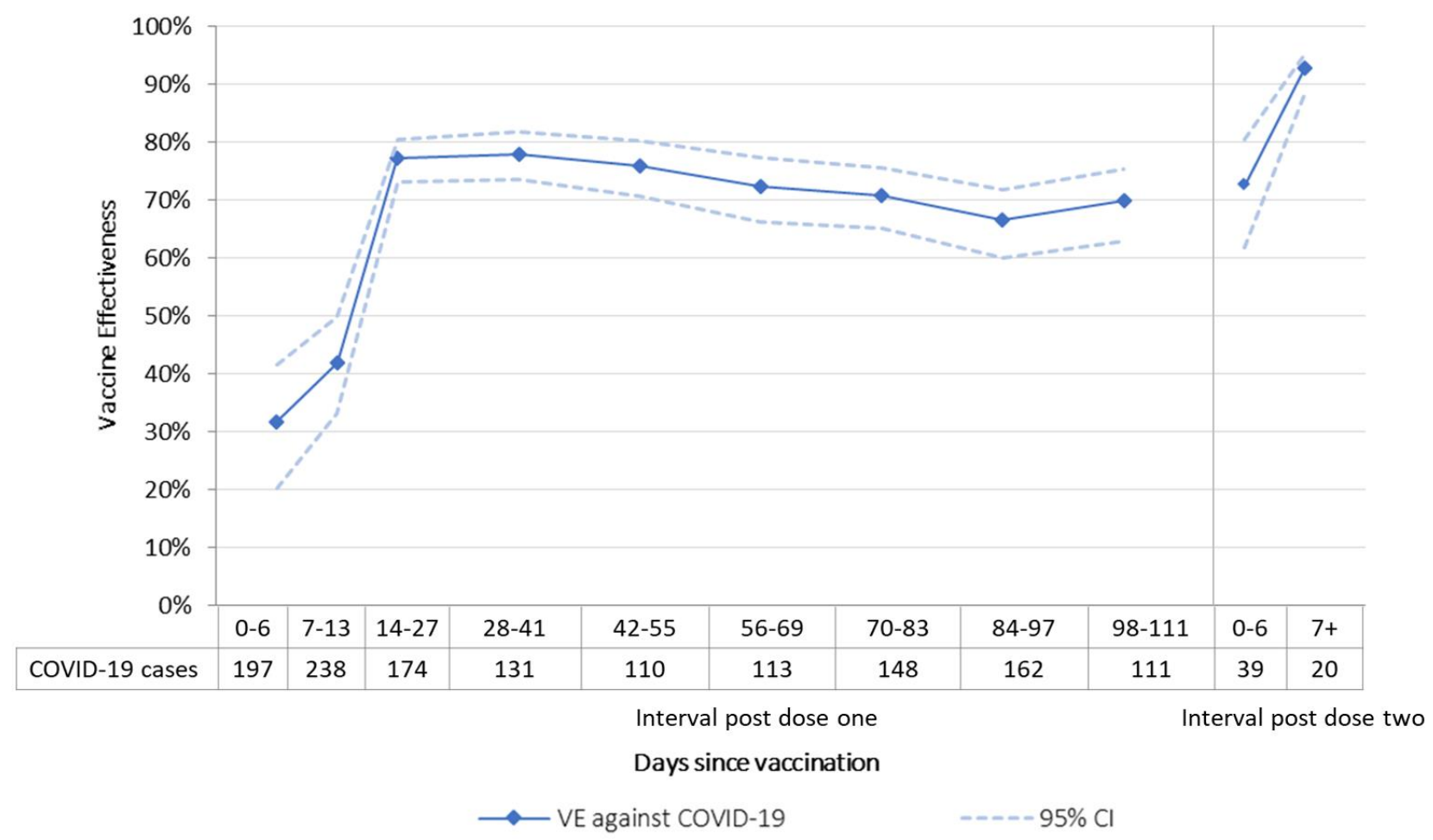

Abbreviations: $\mathrm{VE}=\mathrm{Vaccine}$ effectiveness; $\mathrm{Cl}=$ Confidence Interval 
medRxiv preprint doi: https://doi.org/10.1101/2021.07.19.21260445; this version posted July 22, 2021. The copyright holder for this preprint (which was not certified by peer review) is the author/funder, who has granted medRxiv a license to display the preprint in perpetuity.

It is made available under a CC-BY-NC-ND 4.0 International license.

Figure 3. Vaccine effectiveness against COVID-19 in healthcare workers vaccinated before January $31^{\text {st }} 2021$ (highest contacts with patients) and those vaccinated after February $20^{\text {th }} 2021$ (fewer contacts with patients) by interval since vaccination

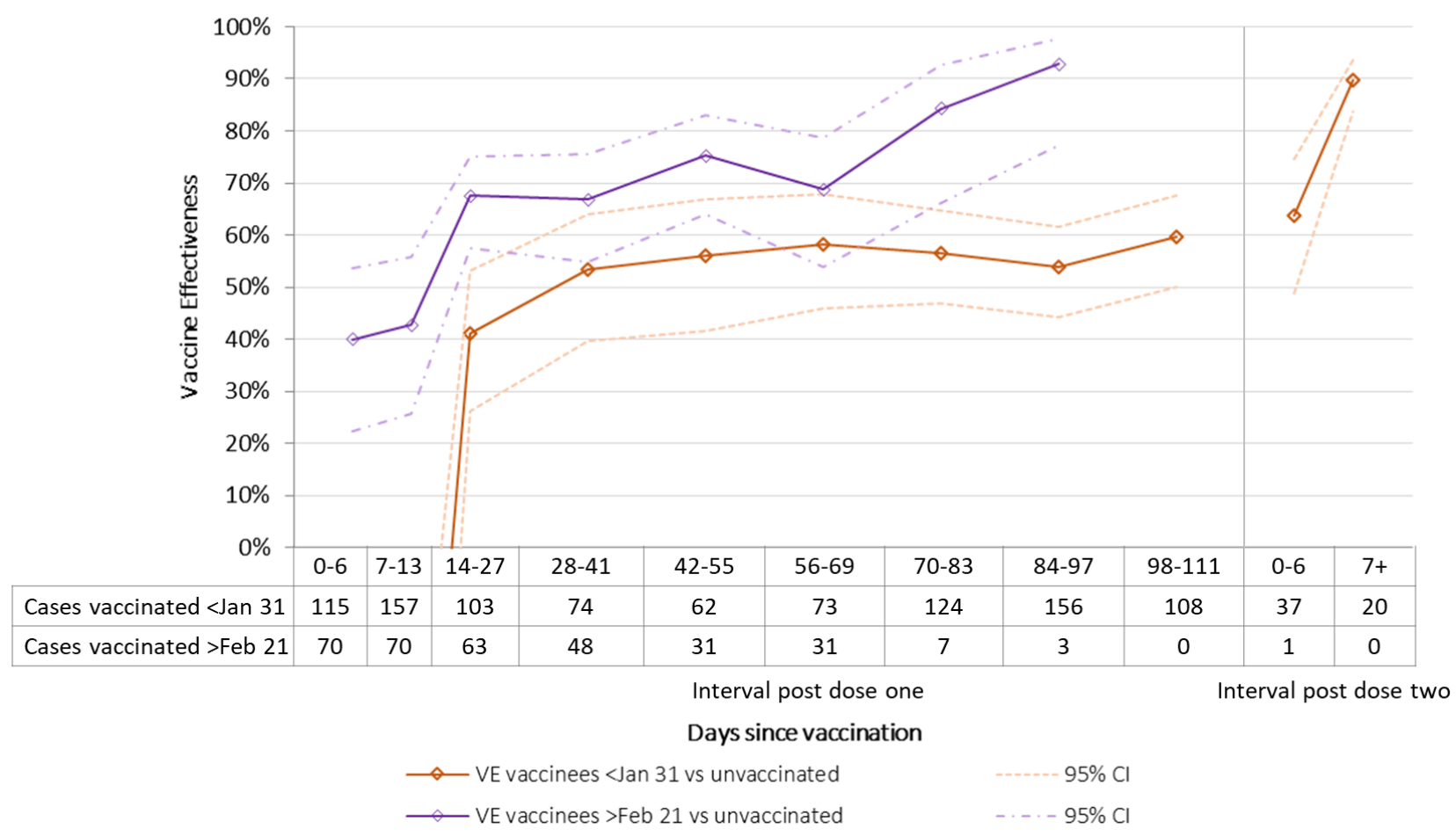

Abbreviations: $\mathrm{VE}=\mathrm{Vaccine}$ effectiveness; $\mathrm{Cl}=$ Confidence Interval 
medRxiv preprint doi: https://doi.org/10.1101/2021.07.19.21260445; this version posted July 22, 2021. The copyright holder for this preprint (which was not certified by peer review) is the author/funder, who has granted medRxiv a license to display the preprint in perpetuity. It is made available under a CC-BY-NC-ND 4.0 International license .

Figure 4. Vaccine effectiveness against COVID-19 by variant of concern (VOC) status (non-VOC or Alpha variant) by interval since vaccination

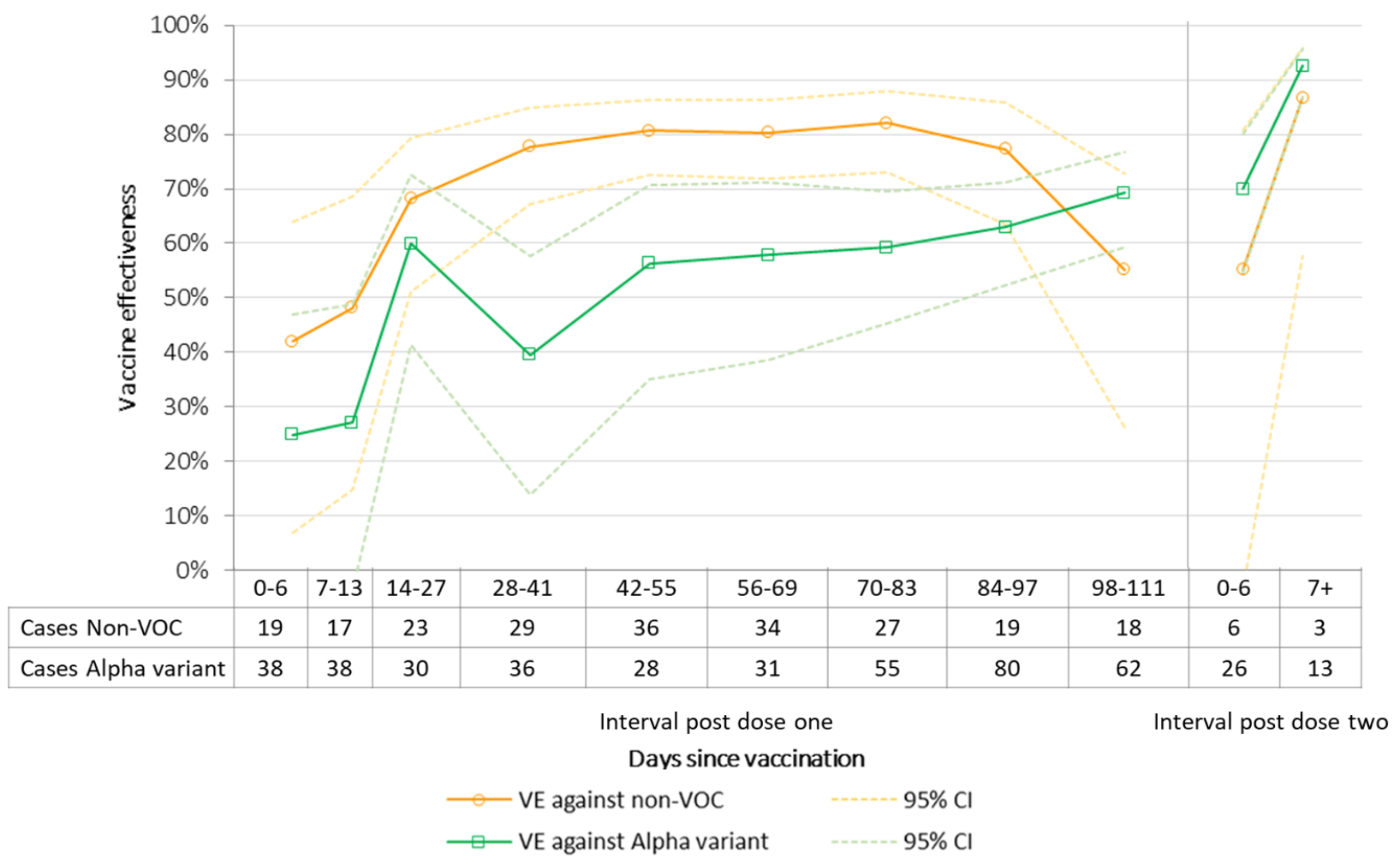

Abbreviations: $\mathrm{VE}=\mathrm{Vaccine}$ effectiveness; $\mathrm{VOC}=$ Variants of concern; $\mathrm{Cl}=$ Confidence Interval 